\title{
PENGARUH IMPLEMENTASI ASESMEN PROJEK TERHADAP HASIL BELAJAR DASAR DAN PENGUKURAN LISTRIK SISWA KELAS X DI SMK NEGERI 1 DENPASAR DENGAN KOVARIABEL KEMAMPUAN NUMERIK
}

\author{
Made Deddy Darmawan, I Made Candiasa, Ni Ketut Widiartini. \\ Program Studi Penelitian dan Evaluasi Pendidikan, Program Pascasarjana \\ Universitas Pendidikan Ganesha \\ Singaraja, Indonesia
}

e-mail: \{deddy.darmawan, made.candiasa, ketut.widiartini\}@pasca.ac.id

\begin{abstract}
Abstrak
Penelitian ini bertujuan untuk mengetahui pengaruh implementasi asesmen projek terhadap hasil belajar dasar dan pengukuran listrik siswa kelas X di SMK Negeri 1 Denpasar dengan kovariabel kemampuan numerik. Penelitian ini menggunakan desain single factor independent groups design with use of covariate dengan teknik analisis kovarian (Anakova) 1 jalur. Populasi penelitian ini adalah seluruh siswa kelas X Teknik Ketenagalistrikan di SMK Negeri 1 Denpasar tahun ajaran 2016/2017. Penelitian ini menggunakan teknik sampling jenuh. Hasil penelitian menunjukkan halhal sebagai berikut (1) Terdapat perbedaan hasil belajar dasar dan pengukuran listrik antara kelompok siswa kelas $\mathrm{X}$ yang mengikuti pembelajaran menggunakan asesmen projek dengan kelompok siswa yang mengikuti pembelajaran dengan asesmen konvensional (t-hitung $=3,5894$ dan $F=12,88379$ ). (2) Terdapat perbedaan hasil belajar dasar dan pengukuran listrik antara kelompok siswa kelas $X$ yang mengikuti pembelajaran menggunakan asesmen projek dengan kelompok siswa yang mengikuti pembelajaran dengan asesmen konvensional setelah diadakan pengendalian pengaruh kemampuan numerik pada siswa kelas $X\left(F^{*}{ }_{A}=30,64\right)$. (3) Kemampuan numerik memiliki kontribusi signifikan terhadap hasil belajar dasar dan pengukuran listrik pada siswa kelas X dengan kontribusi $86,23686 \%$.
\end{abstract}

Kata kunci: Asesmen Projek, Hasil Belajar, Numerik

\begin{abstract}
The purpose of this research are to find out the influence of the assesment implementation project toward the study result of electrical basic and measurement for the tenth grade students in SMKN 1 DENPASAR by numeric covariable ability. The research uses the single factor independent groups design with use of covariate by one line covarian analysis technique (Anacova). The population of the research is all the tenth grade students 2016-2017 electrical program in SMK Negeri 1 Denpasar. This research uses the saturate sampling method. The result of the study show some result: (1) There are diferences in the study result of the basic study and measurement between the students who joint assesment implementation project and those who use conventional method (t: 3, 5894 and F: 12,88379). (2) There are differences between the students who joint the project and who don't joint the project assesment after the numeric assesment influence the students ability (F: 30,64). (3) Numeric ability had significant influence towards the study result of electrical basic and measurement $(86,23686 \%)$.
\end{abstract}

Keywords: project assesment, study result, numeric 
Jurnal_ep, Vol. 8 No. 2, Agustus 2018

\section{PENDAHULUAN}

Dewasa ini pendidikan di Indonesia berkembang sangat pesat seiring perkembangan ilmu pengetahuan dan teknologi (IPTEK) sehingga dalam penyelenggaraan pendidikan di Indonesia diharapkan bisa mengasilkan sumber daya manusia (SDM) yang sesuai dengan kebutuhan dunia industri serta dunia usaha (DU/DI) yang menjadi tantangan tersendiri bagi penyelenggara pendidikan.

Posisi pendidikan di Indonesia sudah menjadi salah satu bagian atau pondasi bagi pembangunan negara, dimana tingkat taraf hidup maupun ekonomi juga akan meningkat apabila kualitas sumber daya manusia (SDM) di Indonesia meningkat dengan menggunakan peran pendidikan. Selain hal tersebut produktifitas dari sumber daya manusia (SDM) yang baik tentunya akan mengasilkan suatu gebrakan bagi suatu negara. Lembaga pendidikan disini berperan dalam mensukseskan produksi kualitas sumber daya manusia (SDM), yang juga harus memiliki suatu inovasi dalam mendidik peserta didiknya untuk menjadi tenaga profesional.

Pendidikan di sekolah menengah kejuruan (SMK) bertujuan untuk mempersiapkan lulusan para peserta didiknya untuk siap bekerja di dunia kerja. Sehingga lulusan yang terampil dan unggul adalah suatu output yang seharusnya wajib dihasilkan oleh sekolah menengah kejuruan (SMK). Oleh karena itu, untuk memenuhi kebutuhan dunia industri ataupun dunia kerja saat ini peran dunia pendidikan yang dinaungi oleh lembaga pendidikan haruslah berkembang dan melakukan pembaharuan.

Undang-Undang Sistem Pendidikan Nasional No. 20 tahun 2003 menjelaskan bahwa pendidikan merupakan suatu usaha sadar dan terencana untuk mewujudkan suasana belajar dan proses pembelajaran agar peserta didik secara aktif mengembangkan potensi dirinya untuk memiliki kekuatan spiritual, keagamaan, pengendalian diri, kepribadian, kecerdasan, akhlak mulia serta keterampilan yang diperlukan dirinya, masyarakat, bangsa dan negara. Dengan demikian, pendidikan merupakan proses mengembangkan potensi siswa secara menyeluruh sehingga potensi yang dimiliki bermanfaat dan membawa kemajuan dalam bidang pendidikan.

Dalam dunia pendidikan tidak hanya lembaga pendidikan khususnya sekolah menengah kejuruan (SMK) saja yang harus berkembang dan melakukan pembaharuan tetapi proses pembelajaran dikelas juga harus diperhatikan yang dipengaruhi oleh peserta didik, pendidik dan sarana pendidikan. Proses pembelajaran dikelas dapat mencakup perencanaan proses pembelajaran, pelaksanaan proses pembelajaran, dan penilaian dari proses pembelajaran. Penilaian dari proses pembelajaran dapat dilakukan dengan mengumpulkan hasil kerja siswa (portofolio), penilaian diri (self assesment), penilaian sikap, penilaian unjuk kerja (performance assesment), penilaian produk (product assesment), dan penilaian projek (project assesment).

Fakta di sekolah berdasarkan hasil studi pendahuluan yang dilakukan pada 8 orang guru produktif teknik ketenagalistrikkan di SMK Negeri 1 Denpasar mengenai penggunaan asesmen autentik dalam pembelajaran diperoleh bahwa: (1) sebanyak $100 \%$ atau seluruh guru belum pernah dan merasa bingung untuk membuat instrumen penilaian hasil belajar sesuai dengan penggunaan asesmen autentik; (2) sebanyak $62,5 \%$ atau 5 orang guru yang merasa kesulitan dalam membuat instrumen penilaian; (3) sebanyak $25 \%$ atau 2 orang guru tidak memahami mengenai asesmen autentik dan memilih untuk melakukan penilaian tes ulangan dan menilai hasil kerja dalam praktik saja.

Berdasarkan pemaparan diatas penggunaan asesmen atau penilaian yang tepat juga perlu diperhatikan, karena tugas pokok guru adalah merencanakan proses pembelajaran dengan menyusun rencana pelaksanaan pembelajaran sebagai output nya, melakukan proses pembelajaran dengan menerapkan model-model pembelajaran yang inovatif serta melakukan judgement atau asesmen dalam melakukan penilaian yang nyata (autentik). Oleh karena itu, sebagai salah satu tugas pokok guru dalam pembelajaran, yakni melakukan asesmen seharusnya menggunakan asesmen yang tepat dan bukan menggunakan asesmen yang 
bersifat konvensional dimana hanya menitik beratkan atau memprioritaskan kemampuan kognitif saja.

Asesmen menurut gabungan teori dari Griffin dan Nix (dalam Widoyoko, 2009), Popham (dalam Widoyoko, 2009), Jihad dan Haris (dalam Kunandar, 2013) dan Kunandar (2013) adalah suatu rangkaian kegiatan untuk memperoleh, menganalisis, dan menafsirkan data tentang proses hasil belajar peserta didik baik secara individu ataupun kelompok yang digunakan dalam pengambilan keputusan tentang pencapaian kompetensi dan status peserta didik berkenaan dengan kepentingan pendidikan.

Asesmen projek berdasarkan gabungan teori dari Dantes (2014), Marhaeni (2008), Kunandar (2014) dan Widoyoko (2014) adalah kegiatan penilaian terhadap suatu topik nyata meliputi: pengumpulan, pengorganisasian, pengevaluasian dan penyajian data yang harus diselesaikan peserta didik (individu/kelompok) dalam periode/waktu tertentu di luar kegiatan pembelajaran di kelas/laboratorium/bengkel.

Asesmen projek menurut Marhaeni (2008) dapat digunakan untuk mengetahui pemahaman, kamampuan mengaplikasikan, kamampuan penyelidikan dan kemampuan menginformasikan dari siswa pada mata pelajaran tertentu secara jelas. Dalam penilaian projek setidaknya ada 3 (tiga) hal yang perlu dipertimbangkan, yaitu: (1) kemampuan pengelolaan, kemampuan peserta didik dalam memilih topik, mencari informasi dan mengelola waktu pengumpulan data serta penulisan laporan. (2) relevansi, kesesuaian dengan mata pelajaran dengan memepertimbangkan tahap pengetahuan, pamahaman dan keterampilan dalam pembelajaran. (3) keaslian, projek yang dilakukan peserta didik harus merupakan hasil karyanya dengan mempertimbangkan kontribusi guru berupa petunjuk dan dukungan terhadap projek peserta didik.

Teknik asesmen projek dilakukan mulai dari perencanaan, proses pengerjaan, sampai hasil akhir projek. Untuk itu, guru perlu menetapkan hal-hal atau tahapan yang perlu dinilai, seperti penyusunan desain, pengumpulan data, analisis data dan menyiapkan laporan tertulis. Laporan tugas atau hasil penelitian juga dapat disajikan dalam bentuk poster. Pelaksanaan penilaian dapat menggunakan alat/instrumen penilaian berupa daftar cek ataupun skala penilaian. Beberapa contoh kegiatan siswa dalam penilaian projek, misalnya penelitian sederhana tentang dampak limbah terhadap kesehatan, pementasan drama, dan sebagainya (Marhaeni, 2008).

Berdasarkan uraian di atas dapat ditemukan beberapa alasan tentang mengapa penilaian projek (project assesment) harus diterapkan ada pembelajaran bidang kelistrikkan di sekolah menengah kejuruan (SMK), seperti (1) guru mampu dalam memonitoring bagaimana perkembangan dan pencapaian kemampuan dari siswa dalam pembelajaran kelistrikkan (dasar dan pengukuran listrik) secara individual, dan (2) memberi kesempatan siswa dalam mengembangkan kemampuannya dalam mengevaluasi dirinya sendiri terhadap hasil karyanya dan tentunya memberikan kesempatan bagi siswa untuk dapat memperbaiki kesalahan-kesalahannya.

Asesmen konvensional menurut Rusmayani (2014) adalah penilaian dilakukan hanya menilai aspek pengetahuan konsep siswa saja tanpa ada penilaian secara menyeluruh mengenai kegiatan pembelajaran yang berkesinambungan yang dimulai dari proses hingga hasil akhir.

Dalam proses pembelajaran, guru juga harus memperhatikan karakteristik kemampuan siswa yang beragam sehingga guru tidak menyamakan karakteristik kemampuan siswa satu dengan siswa yang lainnya. Hal ini lah yang sering kurang diperhatikan oleh sebagian besar guru di sekolah menengah kejuruan (SMK), dari berbagai jenis karakteristik kemampuan siswa yang ada dan tepat digunakan dalam bidang kelistrikan yang dalam pembelajarannya menggunakan kemampuan intelektual siswa, terutama dalam penalaran berhitung dan berpikir secara logis yang terlihat dalam kemampuan kuantitatif, ketelitian dan keakuratan siswa dalam mengerjakan sesuatu yang nantinya akan berperan 
dalam menyelesaikan projek yang telah diberikan sehingga siswa akan mampu mengembangkan kemampuannya.

Kemampuan numerik berdasarkan gabungan teori dari Rusmayani (2014), Suparno (2004) dan Supatni (2015) adalah kemampuan yang dimiliki siswa dalam melakukan operasi hitung serta penggunaan bilangan dan logika secara efektif meliputi operasional penjumlahan, pengurangan, perkalian, pembagian, perpangkatan, penarian akar dan lain sebagainya yang memungkinkan untuk berkembang dan berprestasi di bidang ilmu pasti dengan indikator-indikator: (1) mengidentifikasi sifat-sifat bilangan berpangkat dan bentuk akar, (2) mengidentifikasi masalah yang berkaitan dengan operasi pertambahan, pengurangan, perkalian atau pembagian, (3) mendefinisikan masalah yang berkaitan dengan operasi bilangan aritmatika sederhana, (4) mengidentifikasi skala dan perbandingan, (5) memahami sifat-sifat tabung, kerucut, bujur sangkar dan bola serta menentukan ukurannya, (6) Menghitung sudut bangun segi empat serta menggunakannya dalam pemecahan, (7) menentukan penyelesaian sistem persamaan linier dan sistem persamaan campuran linier dan kuadrat dalam dua variabel.

Hasil belajar menurut gabungan teori dari Bloom (dalam Rusmayani, 2014) dengan Dimyati dan Mudjiono (2015) yakni hasil dari suatu interaksi tindak belajar dan tindak mengajar yang menghasilkan kemampuan-kemampuan baru meliputi ranah kognitif, afektif, dan psikomotorik. Sehingga hasil belajar dasar dan pengukuran listrik adalah hasil akhir dari proses kegiatan belajar siswa dari seluruh kegiatan dalam mengikuti pembelajaran dasar dan pengukuran listrik untuk mencapai kompetensi yang telah ditentukan meliputi indikator-indikator: (1) menjelaskan rangkaian sinusoida, (2) menjelaskan respon elemen pasif, (3) menganalisis rangkaian seri/paralel $R L, R C$, \& RLC, (4) mengidentifikasi resonansi, menguraikan daya dan faktor daya, (6) mengemukakan sistem tiga fasa, (7) menerapkan fasor dan bilangan komplek, (8) menerapkan rangkaian kemagnetan.
Permasalahan yang muncul berdasarkan pengamatan peneliti bahwa guru mata pelajaran dasar dan pengukuran listrik masih belum tepat dalam menggunakan asesmen dalam proses pembelajaran dan kemampuan numerik yang dimiliki oleh siswa kurang dipertimbangkan dalam perancangan pembelajaran.

Berdasarkan uraian di atas dapat diduga bahwa: (1) Terdapat perbedaan hasil belajar dasar dan pengukuran listrik antara kelompok siswa kelas $X$ yang mengikuti pembelajaran menggunakan asesmen projek dengan kelompok siswa yang mengikuti pembelajaran dengan asesmen konvensional. (2) Terdapat perbedaan hasil belajar dasar dan pengukuran listrik antara kelompok siswa kelas $X$ yang mengikuti pembelajaran menggunakan asesmen projek dengan kelompok siswa yang mengikuti pembelajaran dengan asesmen konvensional setelah diadakan pengendalian pengaruh kemampuan numerik pada siswa kelas X. (3) Kemampuan numerik memiliki kontribusi signifikan terhadap hasil belajar dasar dan pengukuran listrik pada siswa kelas $X$.

\section{METODE PENELITIAN}

Rancangan penelitian ini menggunakan desain single factor independent groups design with use of covariate (Dantes, 2012) dan menggunakan rancangan analisis penelitian yakni analisis kovarian (ANAKOVA) 1 jalur. Populasi pada penelitian ini adalah seluruh siswa kelas $X$ Teknik Ketenagalistrikan di SMK Negeri 1 Denpasar tahun ajaran 2016/2017, berjumlah 74 orang yang tersebar menjadi 2 kelas yakni kelas X TL dengan 38 orang siswa dan XI TP dengan 36 orang siswa.

Hasil uji kesetaraan diperoleh hasil bahwa kedua kelas dinyatakan setara dan untuk menentukan sampel pada penelitian ini menggunakan teknik sampling jenuh (Sugiyono, 2014:117). Penentuan kelompok kelas eksperimen dan kelompok kelas kontrol dengan cara di undi. Dengan demikian diperoleh hasil kelompok kelas eksperimen adalah kelas $X$ TP dan kelompok kelas kontrol adalah kelas X TL di SMK Negeri 1 Denpasar. 
Penelitian ini menggunakan beberapa variabel yang dapat dijabarkan sebagai berikut ini. (1) Variabel terikat pada penelitian ini adalah hasil belajar (Y). (2) Variabel bebas pada penelitian ini adalah model pembelajaran dan asesmen belajar yang dikelompokan menjadi pembelajaran dengan asesmen projek $\left(A_{1}\right)$ dan pembelajaran dengan asesmen konvensional $\left(A_{2}\right)$. (3) Variabel kendali yakni kemampuan numerik $(\mathrm{X})$.

Data yang diperoleh dari penelitian ini didapatkan melalui dua macam tes, yakni tes hasil belajar dan tes kemampuan numerik. Validasi instrumen (Candiasa, 2010) yang dilakukan untuk tes hasil belajar dan tes kemampuan numerik terdiri dari uji validitas, uji reliabilitas, uji daya beda, uji tingkat kesukaran, dan efektifitas pengecoh.

Metode analisis data dalam penelitian ini meliputi uji prasyarat analisis dengan uji normalitas, uji homogenitas, uji linieritas dan keberartian arah regresi serta pengujian hipotesis, yakni uji hipotesis pertama dengan menggunakan uji-t (Candiasa, 2011) sebagai berikut:

$t=\frac{\overline{Y_{1}}-\overline{Y_{2}}}{\sqrt{\frac{s^{2}}{n_{1}}+\frac{s^{2}}{n_{2}}}}$

Selanjutnya untuk mengetahui pengaruh kemampuan numerik yang ditarik dari hasil belajar siswa perlu dicari nilai $F$ dengan menggunakan uji $\mathrm{F}$ sebagai berikut.

$F=t^{2}$

Uji hipotesis kedua dengan menggunakan uji analisis kovarian (ANAKOVA) (Candiasa, 2011) sebagai berikut:

$\mathrm{F}^{*}=\frac{R J K_{A}^{*}}{R J K_{D}^{*}}$

Uji hipotesis ketiga dengan menggunakan uji regresi sederhana (Candiasa, 2011) sebagai berikut:

$r_{x y}=\frac{N \sum X Y-\left(\sum X\right)\left(\sum Y\right)}{\sqrt{\left\{N \sum X^{2}-\left(\sum X\right)^{2}\right\}\left[N \sum Y^{2}-\left(\sum Y\right)^{2}\right\}}}$

Koefisien korelasi antara variabel bebas $(\mathrm{X})$ dengan variabel terikat $(\mathrm{Y})$ juga dapat digunakan untuk menentukan kontribusi variabel bebas $(X)$ terhadap variabel terikat $(Y)$. Kontribusi dapat ditentukan dengan koefisien determinasi $r^{2} x y$ yang merupakan kuadrat dari korelasi $r_{x y}$.

Selanjutnya untuk menentukan derajat korelasi product moment $\left(r_{\mathrm{xy}}\right)$, dapat digunakan kriteria yang dikemukakan oleh Guilford (Dantes, 2012) sebagai berikut.

Tabel 1. Kriteria Guilford

\begin{tabular}{cc}
\hline Rentangan & Kriteria \\
\hline$\leq 0,20$ & Sangat Rendah \\
\hline $0,20 \leq 0,40$ & Rendah \\
\hline $0,40 \leq 0,60$ & Sedang \\
\hline $0,60 \leq 0,80$ & Tinggi \\
\hline $0,80 \leq 1,00$ & Sangat Tinggi \\
\hline
\end{tabular}

\section{HASIL PENELITIAN DAN PEMBAHASAN}

Uji prasyarat yang perlu pengujian dalam penelitian ini adalah normalitas, homogenitas dan linieritas. Diperoleh hasil data berasal dari populasi berdistribusi normal, data berasal dari populasi yang homogeny, dan regresi yang kita peroleh berarti serta bentuk regresi linier.

Uji hipotesis dalam penelitian ini melalui metode statistik dengan formula sebagai berikut:

Pertama, uji-t diperoleh hasil perhitungan sebagai berikut.

Tabel 2. Hasil Perhitungan Uji-t

Kelompok Sampel $\quad t_{- \text {hitung }} t_{\text {-tabel }} \quad F_{\text {-hitung }}$




\section{\begin{tabular}{llll}
$\mathrm{A}_{1} \mathrm{Y}$ dan $\mathrm{A}_{2} \mathrm{Y}$ & 3,5894 & 1,99346 & 12,88379 \\
\hline
\end{tabular}}

Berdasarkan tabel di atas diperoleh hasil t-hitung $(3,5894)$ lebih besar daripada t-tabel $(1,99346)$ sehingga $\mathrm{H}_{0}$ ditolak dan $\mathrm{H}_{1}$ diterima. Jadi terdapat perbedaan hasil belajar dasar dan pengukuran listrik antara kelompok siswa kelas $X$ yang mengikuti pembelajaran menggunakan asesmen projek dengan kelompok siswa yang mengikuti pembelajaran dengan asesmen konvensional di SMK Negeri 1 Denpasar.

Perbedaan hasil belajar dasar dan pengukuran listrik antara kelompok siswa kelas $X$ yang mengikuti pembelajaran menggunakan asesmen projek dengan kelompok siswa yang mengikuti pembelajaran dengan asesmen konvensional dipengaruhi oleh berbagai faktor, diantaranya adalah asesmen pembelajaran yang digunakan guru. Penggunaan asesmen yang tepat perlu diperhatikan, karena tugas pokok guru adalah merencanakan proses pembelajaran dengan menyusun rencana pelaksanaan pembelajaran sebagai output nya, melakukan proses pembelajaran dengan menerapkan model-model pembelajaran yang inovatif serta melakukan judgement atau asesmen dalam melakukan penilaian yang nyata (autentik). Dengan demikian guru hendaknya mampu memilih dan memilah asesmen yang digunakan dalam pembelajaran dan disesuaikan dengan karateristik siswa dan keberagaman kemampuan yang dimiliki siswa, sehingga tujuan pembelajaran atau kompetensi yang sudah ditetapkan tercapai. Pembelajaran dengan asesmen projek terbukti lebih baik dalam peningkatkan hasil belajar dasar dan pengukuran listrik siswa kelas $X$ daripada pembelajaran dengan asesmen pembelajaran konvensional yang biasa digunakan guru di SMK Negeri 1 Denpasar.

Hasil uji statistik diatas sesuai dengan hasil penelitian dari Sri Yulianti (2014) menunjukan bahwa model pembelajaran disertai asesmen projek berpengaruh terhadap hasil belajar matematika siswa kelas XII di SMA Negeri 1 Semarapura. Dari hasil penelitian yang telah dipaparkan di atas sangatlah logis bahwa asesmen projek yang digunakan dalam pembelajaran memberikan hasil yang lebih baik daripada asesmen yang biasa digunakan (konvensional), sehingga telah terbukti secara empiris dalam penelitian ini, bahwa hasil belajar dasar dan pengukuran siswa kelas $X$ yang mengikuti pembelajaran dengan asesmen projek lebih baik daripada siswa kelas $X$ yang mengikuti pembelajaran dengan menggunakan asesmen konvensional.

Berdasarkan hasil penelitian ini guru perlunya menyadari bahwa tidak semua pokok bahasan cocok dinilai dengan dengan penilaian yang sama dalam kaitannya untuk meningkatkan hasil belajar siswa. Perlu disadari bahwa beberapa asesmen autentik atau nyata yang ada dapat digunakan oleh guru dalam proses pembelajaran untuk mencapai tujuan pembelajaran yang telah ditetapkan sebelumnya.

Kedua, analisis kovarian (anakova) diperoleh hasil perhitungan sebagai berikut.

Tabel 3. Hasil Perhitungan Anakova 1 Jalur

\begin{tabular}{cccccccc}
\hline $\begin{array}{c}\text { Sumber } \\
\text { Variasi }\end{array}$ & JK & $\mathbf{d b}$ & $\mathbf{R K}$ & $\mathbf{F A}^{*}$ & \multicolumn{2}{c}{$\mathbf{F}$ Tabel } & Keterangan \\
\cline { 6 - 8 } & & & & & $\mathbf{5 \%}$ & $\mathbf{1 \%}$ & \\
\hline Antar & 189,07 & 1 & 189,07 & 30,64 & 3,98 & 7,01 & Signifikan \\
\hline Dalam (error) & 438,17 & 71 & 6,17 & - & - & - & - \\
\hline Total (residu) & 627,24 & 72 & - & - & - & - & - \\
\hline
\end{tabular}

Berdasarkan tabel di atas diperoleh perhitungan $\mathrm{F}^{*}{ }_{\mathrm{A}}=30,64$ sedangkan $\mathrm{F}_{(0,05 ; 1}$ : 71) $=3,98$. Berarti $F_{A}^{*}>F_{(0,05 ; 1: 71)}$. Sesuai dengan kriteria pengujian maka $\mathrm{H}_{1}$ diterima, sebaliknya $\mathrm{H}_{0}$ ditolak. Sehingga terdapat perbedaan hasil belajar dasar dan pengukuran listrik antara kelompok siswa kelas $X$ yang mengikuti pembelajaran menggunakan asesmen projek dengan kelompok siswa yang mengikuti pembelajaran dengan asesmen konvensional setelah diadakan 
pengendalian pengaruh kemampuan numerik pada siswa kelas $X$.

Perbedaan hasil belajar dasar dan pengukuran listrik antara kelompok siswa kelas $X$ yang mengikuti pembelajaran menggunakan asesmen projek dengan kelompok siswa yang mengikuti pembelajaran dengan asesmen konvensional setelah diadakan pengendalian pengaruh kemampuan numerik pada siswa kelas $X$ dipengaruhi oleh kemampuan numerik siswa yang dibagi menjadi yakni siswa yang memiliki kemampuan numerik tinggi dengan siswa yang miliki kemampuan numerik yang rendah. Siswa yang memiliki kemampuan numerik tinggi lebih cenderung untuk suka tantangan dan pantang menyerah dalam menghadapi dan menyelesaikan suatu masalah atau kendala yang dihadapi saat diberikan suatu tugas sedangkan siswa yang memiliki kemampuan numerik yang rendah kurang memiliki semangat dalam mengerjakan suatu tugas tertentu, kurang suka saat mendapatkan tantangan dan terkesan menghindari tugas yang dianggap susah sehingga seseorang yang memiliki kemampuan numerik rendah cenderung pasif dalam pembelajaran terutama pada pembelajaran yang membutuhkan pemikiran lebih dalam menyelesaikan suatu tugas berupa projek. Pembelajaran dengan asesmen projek menuntut siswa aktif dan kreatif selama proses pembelajaran saat perencanaan, pelaksanaan maupun hasil akhir sehingga pembelajaran dengan asesmen projek dirasa kurang cocok bagi siswa yang memiliki kemampuan numerik rendah. Hal ini menunjukan bahwa hasil belajar dasar dan pengukuran listrik yang di peroleh siswa memiliki kaitan terhadap kemampuan numerik.

Nilai $F$ yang diperoleh dari uji hipotesis kedua lebih besar dari nilai uji $F$ pada hipotesis yang pertama disebabkan oleh faktor kemampuan numerik yang ditarik sebagai salah satu variabel penelitain yang memiliki pengaruh terhadap hasil belajar siswa pada mata pelajaran dasar dan pengukuran listrik.

Berbagai penelitian pendidikan mengungkapkan bahwa hasil-hasil penelitian yang menerapkan asesmen autentik atau nyata (asesmen projek) dengan dikendalikan oleh kemampuan (numerik) yang dimiliki siswa dalam proses pembelajaran menunjukkan keunggulan yaitu salah satu penelitian yang dilakukan Rusmayani (2014) membuktikan bahwa implementasi asesmen projek dengan pengendalian kemampuan numerik dan ekspektasi karir dibidang informatika mampu berpangaruh terhadap hasil belajar TIK.

Hasil penelitian ini dapat dijadikan guru sebagai pemahaman bahwa kemampuan numerik yang dimiliki siswa merupakan salah satu variabel yang memiliki pengaruh terhadap hasil belajar siswa terutama untuk mata pelajaran dasar dan pengukuran listrik yang dalam pembelajarannya banyak terdapat perhitungan-perhitungan.

Ketiga, uji regresi sederhana diperoleh hasil perhitungan sebagai berikut.

Tabel 4. Hasil Perhitungan Uji Regresi Sederhana

\begin{tabular}{lcccc}
\hline Analisis Regresi Sederhana & $\mathbf{r}$-hitung & $\mathbf{r}$-tabel & $\mathbf{r}^{\mathbf{2}} \mathbf{x y}$ & Kriteria \\
\hline Koefisien korelasi & 0,9286 & 0,3291 & 0,8623686 & Sangat tinggi \\
\hline
\end{tabular}

Berdasarkan tabel di atas diperoleh nilai $r$ hitung $\left(r_{\mathrm{xy}}\right)$ hasil penelitian $(0,9286)$ lebih besar dari $r$ tabel $(0,3291)$. Ini berarti $\mathrm{H}_{0}$ ditolak dan $\mathrm{H}_{1}$ diterima. Jadi korelasi antara $\mathrm{X}$ dengan $\mathrm{Y}$ dengan koefisien korelasi $\left(r_{x y}\right)=0,9286$ berarti atau signifikan atau kemampuan numerik memiliki kontribusi signifikan terhadap hasil belajar dasar dan pengukuran listrik pada siswa kelas $X$. Dari perhitungan diatas juga diperoleh $r^{2} x y=0,9286^{2}=0,8623686$ atau jika diprosentasekan sebesar 86,23686\%. Selanjutnya untuk menentukan derajat korelasi product moment $\left(r_{x y}\right)$, dapat digunakan kriteria yang dikemukakan oleh Guilford diperoleh nilai koefisien korelasi product moment $\left(r_{\mathrm{xy}}\right)$ sebesar 0,9286 termasuk dalam kategori sangat tinggi.

Kemampuan numerik memiliki kontribusi signifikan terhadap hasil belajar 
dasar dan pengukuran listrik pada siswa kelas $\mathrm{X}$ dikarenakan kemampuan numerik merupakan salah satu aspek kemampuan dari siswa yang menyumbang persentase besar terhadap peningkatan hasil belajar terutama pada mata pelajaran dasar dan pengukuran listrik siswa kelas $X$ yang banyak berisikan perhitungan-perhitungan dalam pembelajarannya seperti yang telah dipaparkan dalam penelitian ini.

Hal ini dapat dilihat dari variasi dalam variabel terikat hasil belajar dasar dan pengukuran listrik dapat dijelaskan oleh variabel bebas kemampuan numerik sedangkan sisanya ditentukan oleh variabel lain yang tidak diteliti. Hal ini sesuai dengan hasil penelitian dari Supatni (2015) menunjukkan bahwa model pembelajaran kooperatif tipe Think Pair Share (TPS) dengan kovariabel kemampuan numerik berpengaruh terhadap prestasi belajar siswa kelas VI Di SD Gugus II Bedulu.

Hasil penelitian ini bisa dijadikan acuan bagi guru untuk mempertimbangkan kemampuan yang dimiliki siswa sebagai salah satu aspek yang mempengaruhi hasil belajar siswa yang memiliki kontribusi khususnya pada mata pelajaran dasar dan pengukuran listrik yang banyak berisikan perhitungan-perhitungan sehingga kemampuan numerik siswa perlu diperhatikan.

\section{PENUTUP}

Berdasarkan hasil penelitian dan pembahasan, dapat diuraikan menjadi tiga temuan hasil penelitian yang merupakan jawaban terhadap tiga masalah yang diajukan dalam penelitian ini. Temuantemuan tersebut adalah sebagai berikut.

Pertama, hasil belajar dasar dan pengukuran listrik siswa kelas $\mathrm{X}$ di SMK Negeri 1 Denpasar antara siswa yang mengikuti pembelajaran dengan asesmen projek lebih tinggi daripada siswa yang mengikuti pembelajaran dengan asesmen konvensional diperoleh nilai rata-rata siswa yang mengikuti pembelajaran dengan asesmen projek lebih besar dari nilai ratarata siswa yang mengikuti pembelajaran dengan asesmen konvensional. $\mathrm{Hal}$ ini berarti hipotesis nol $\left(\mathrm{H}_{0}\right)$ ditolak dan hipotesis alternatif $\left(\mathrm{H}_{1}\right)$ diterima. Sehingga dapat dikatakan bahwa terdapat perbedaan hasil belajar dasar dan pengukuran listrik antara kelompok siswa kelas $X$ yang mengikuti pembelajaran menggunakan asesmen projek dengan kelompok siswa yang mengikuti pembelajaran dengan asesmen konvensional.

Kedua, hasil belajar dasar dan pengukuran listrik siswa kelas $X$ di SMK Negeri 1 Denpasar antara siswa yang mengikuti pembelajaran dengan asesmen projek lebih baik daripada siswa yang mengikuti pembelajaran dengan asesmen konvensional setelah dikendaikan oleh kovariabel kemampuan numerik. Dengan demilkian hipotesis nol $\left(\mathrm{H}_{0}\right)$ ditolak dan hipotesis alternatif $\left(\mathrm{H}_{1}\right)$ diterima. sehingga dapat dikatakan bahwa terdapat perbedaan hasil belajar dasar dan pengukuran listrik antara kelompok siswa kelas $X$ yang mengikuti pembelajaran menggunakan asesmen projek dengan kelompok siswa yang mengikuti pembelajaran dengan asesmen konvensional setelah diadakan pengendalian pengaruh kemampuan numerik pada siswa kelas $X$.

Ketiga, kemampuan numerik memiliki kontribusi terhadap hasil belajar dasar dan pengukuran listrik pada siswa kelas $X$ di SMK Negeri 1 Denpasar. Hal ini berarti sekitar $86,23686 \%$ variasi dalam variabel terikat $Y$ (hasil belajar dasar dan pengukuran listrik) dijelaskan oleh variabel $X$ (Kemampuan numerik), sedangkan sisanya ditentukan oleh variabel yang lain sebesar 23.104\%. Sehingga dapat dikatakan bahwa kemampuan numerik memiliki kontribusi signifikan terhadap hasil belajar dasar dan pengukuran listrik pada siswa kelas $\mathrm{X}$.

Berdasarkan temuan-temuan di atas disimpulkan bahwa terdapat pengaruh implementasi asesmen projek terhadap hasil belajar dasar dan pengukuran listrik siswa kelas $X$ di SMK Negeri 1 Denpasar dengan kovariabel kemampuan numerik.

Saran yang disampaikan dibagi menjadi tiga bagian. Pertama, saran-saran kepada guru yang terkait dengan kebermanfaatan temuan ini untuk pembelajaran. Kedua, saran-saran kepada peneliti lain untuk kemungkinan pelaksanaan penelitian lebih lanjut.

Dalam upaya untuk penyebaran dan pemanfaatan hasil penelitian ini, maka ada 
beberapa saran yang diajukan kepada guru, yaitu sebagai berikut.

Pertama, para guru mata pelajaran dasar dan pengukuran listrik kelas $X$ di SMK khususnya di SMK Negeri 1 Denpasar hendaknya menggunakan asesmen yang sesuai dengan model pembelajaran dalam rangka meningkatkan hasil belajar dasar dan pengukuran listrik siswa.

Kedua, agar hasil belajar dasar dan pengukuran listrik siswa kelas $\mathrm{X}$ dapat ditingkatkan, guru disarankan mempertimbangkan kemampuan numerik siswa. Pada kelompok siswa dengan kemampuan numerik tinggi, model pembelajaran dengan asesmen projek sangat tepat diterapkan. Sedangkan pada kelompok siswa dengan kemampuan numerik yang rendah, hendaknya kemampuan numerik siswa dikembangkan terlebih dahulu, setelah itu model pembelajaran dengan asesmen projek ini dapat diterapkan lebih efektif.

Bagi para praktisi pendidikan dan guru yang ingin mengembangkan model pembelajaran dengan asesmen projek dan memperhatikan kemampuan numerik dalam pembelajaran dan atau melaksanakan penelitian lebih lanjut yang berkaitan dengan hasil-hasil penelitian ini, maka ada beberapa hal yang disampaikan sebagai saran.

Pertama, penelitian ini ada beberapa kendala dan keterbatasan yang dialami peneliti salah satunya yakni keterbatasan waktu. Banyaknya jam-jam yang tidak efektif atau banyaknya hari-hari libur yang digunakan untuk persiapan ujian kelas XII di SMK mulai dari ujian tulis dan ujian praktek dan kegiatan-kegiatan lainnya. Pengalaman ini bisa dijadikan pelajaran untuk mempersiapkan jadwal penelitian sedini mungkin sehingga tidak terbentur dengan kegiatan yang ada di sekolah tempat penelitian dilakukan.

Kedua, materi pembelajaran yang digunakan dalam penelitian ini terbatas hanya pada beberapa kompetensi dasar dalam mata pelajaran dasar dan pengukuran listrik, sehingga dapat dikatakan bahwa hasil-hasil penelitian terbatas hanya pada materi tersebut. Untuk mengetahui kemungkinan hasil yang berbeda pada pokok bahasan dan jenjang pendidikan lainnya, peneliti menyarankan kepada peneliti selanjutnya untuk melakukan penelitian yang sejenis pada pokok bahasan dan jenjang pendidikan yang lain.

\section{DAFTAR RUJUKAN}

Candiasa. 2011. Statistik Multivariat Disertai Aplikasi SPSS. Singaraja: Undiksha Press.

Candiasa. 2011. Pengujian Instrumen Penelitian Disertai Aplikasi ITEMAN dan BIGSTEPS. Singaraja: Undiksha Press.

Candiasa. 2010. Statistik Univariat dan Bivariat Disertai Aplikasi SPSS. Singaraja: Undiksha Press.

Dantes. 2012. Metode Penelitian. Yogyakarta: ANDI.

Dantes. 2014. Landasan Pendidikan Tinjauan Dari Dimensi Makropedagogis. Yogyakarta: Graha IImu.

Dimyati dan Mudjiono. 2015. Belajar \& Pembelajaran. Jakarta: Rineka Cipta.

Kunandar. 2013. Penilaian Autentik (Penilaian Hasil Belajar Peserta Didik Berdasarkan Kurikulum 2013). Jakarta: PT Rajagrafindo Persada.

Marhaeni. 2008. Pembelajaran Berbasis Asesmen Otentik dalam Rangka Implementasi Sekolah Kategori Mandiri (SKM). Makalah, disajikan pada Pelatihan Peningkatan Kinerja Guru SMA 1 Kediri Tabanan, dalam Rangka Implementasi SKM, tanggal 30 Desember 2008.

Rusmayani. 2013. Pengaruh Implementasi Asesmen Projek Terhadap Hasil Belajar Tik Dengan Kovariabel Kemampuan Numerik Dan Ekspektasi Karir Bidang Informatika (Studi Pada Siswa Kelas XI SMA Dharma Praja Badung) Tahun 2013/2014. Jurnal Penelitian Program Studi Penelitian dan Evaluasi Pendidikan, Program 
Pascasarjana Universitas Pendidikan Ganesha Singaraja, Indonesia.

Sugiyono. 2014. Metode Penelitian Pendidikan Pendekatan Kuantitatif, Kualitatif dan $R \& D$. Bandung: Alfabeta.

Suparno, P. 2004. Teori Intelegensi Ganda dan Aplikasinya di Sekolah Cara Menerapkan Teori Multiple Intellegences Howard Gardner. Yogyakarta: Kanisius.

Supatni, Ni Made. 2015. Pengaruh Model Pembelajaran Kooperatif Tipe Think Pair Share (TPS) Terhadap Prestasi Belajar Matematika Dengan Kovariabel Kemampuan Numerik Siswa Kelas VI Di SD Gugus II Bedulu. Jurnal Penelitian Program Studi Penelitian dan Evaluasi Pendidikan, Program Pascasarjana Universitas Pendidikan Ganesha Singaraja, Indonesia.
Undang-Undang Sistem Pendidikan Nasional No. 20 tahun 2003 tentang pendidikan http://www.kemenag.go.id /file/dokumen/UU2003.pdf (diunduh tanggal 7 September 2016).

Widoyoko, Eko Putro. 2009. Evaluasi Program Pembelajaran. Yogyakarta: Pustaka Pelajar.

Widoyoko, Eko Putro. 2014. Penilaian Hasil Belajar Di Sekolah. Yogyakarta: Pustaka Pelajar.

Yulianti, Sri. 2013. Pengaruh Penggunaan Model Pembelajaran Siklus Belajar Hipotesis- Deduktif Disertai Asesmen Projek Terhadap Hasil Belajar Matematika Siswa Kelas XII IPA SMA Negeri 1 Semarapura Ditinjau Dari Motivasi Berprestasi. Jurnal Penelitian Program Studi Penelitian dan Evaluasi Pendidikan, Program Pascasarjana Universitas Pendidikan Ganesha Singaraja, Indonesia. 